\title{
DENIAL OF FTC RULEMAKING POWERS
}

In National Petroleum Refiners Association v. FTC, ${ }^{1}$ the District Court for the District of Columbia held that the Federal Trade Commission (FTC) lacks the statutory authority ${ }^{2}$ to promulgate Trade Regulation Rules ${ }^{3}$ having the effect of substantive law. Concluding that a failure to indicate octane numbers on gasoline dispensing pumps could constitute an unfair or deceptive act or practice violative of the Federal Trade Commission Act (FTCA), ${ }^{4}$ the Commis(1973).

1. 340 F. Supp. 1343 (D.D.C. 1972), noted in 18 S. Dakota L. Rev. 243

2. See Federal Trade Commission Act, 15 U.S.C. $\S \S 41-58$ (1970).

3. The term "Trade Regulation Rule" refers to a legislatively promulgated regulation issued by the FTC following a hearing of industry representatives. Such Trade Regulation Rules are enacted upon the initiative of the Commission, as contrasted with trade practice rules which are often issued on the initiative of the industries involved. See note 18 infra.

4. On July 29,1969 , the FTC filed a notice that it had initiated a proceeding for the promulgation of a Trade Regulation Rule. See 34 Fed. Reg. 12,449 (1969). The new rule, the text of which was contained in the notice, would be issued pursuant to the FTCA, 15 U.S.C. $\$ \$ 41-58$ (1970), and to provisions of Part I, Subpart $B$ of the Commission procedure and rules of practice, 16 C.F.R. $\$ \S$ 1.11-16 (1972). The FTC proposal was addressed to the subject of mandatory posting of research octane numbers on gasoline dispensing pumps by refiners and other inarketers of gasoline. Id.

Octane numbers or ratings are a desiguation of the anti-knock qualities of a gasoline. The research method is but one of several means of determining this property, the motor method being another. The FTC stated that it had initiated the proceeding having reason to believe that not to so post octane ratings may constitute deception and an unfair trade practice. The Commission argued that failure to post ratings could result in consumers either purchasing gasoline with an unnecessarily high octane rating and thereby wasting money, or purchasing a "sub-regular" gasoline which could cause engine damage. It was stated that where the Trade Regulation Rule was relevant in further adjudication, the Commission would be able to rely on the rule provided the respondent was given a full hearing on the applicability of the rule in the given case. The notice invited the submission of data and oral presentations and urged the expression of approval or disapproval and the suggestion of amendments to the proposed rule. On December 30, 1970, the Commission issued such a rule, 36 Fed. Reg. 354 (1971), and made a statement supporting its rule-making authority. Referral was made there to the Statement of Basis and Purpose accompanying the Trade Regulation for the Prevention of Unfair or Deceptive Advertising of Labelling of Cigarettes in Relation to the Health Hazards of Smoking, 29 Fed. Reg. 8325 (1964). The Commission delayed the effective date of the rule to September 1, 1971, 36 Fed. Reg. 7309 (1971) in order that it might consider a revision brought about by a subsequent development concerning the lead content of gasoline. This brought into question the appropriateness of utilizing the research method of obtaining octane ratings. The 
sion issued a rule requiring gasoline refiners and marketers to post such ratings. ${ }^{5}$ Thirty-four oil companies and two refimery associations subsequently filed an action contending that the FTC lacked authority under the Federal Trade Commission Act to promulgate such rules. ${ }^{\circ}$ The district court granted plaintiffs' motion for summary judgment, holding that the rule-making power granted in the FTCA $^{7}$ was limited solely to the authority to make procedural rules and regulations in connection with the Commission's investigatory responsibilities and housekeeping chores. ${ }^{8}$

Congressional debate prior to the 1914 enactment of the FTCA $^{9}$ reflected heated controversy over the extent of the powers such an agency should possess. ${ }^{10}$ In its final version, ${ }^{11}$ section 5 of the FTCA empowered the FTC to "prevent" unfair methods of competition-conferring upon the Commission quasi-judicial powers to file complaints, to hold hearings to determine whether violations of the FTCA were occurring, and to issue cease and desist orders to terminate such violations. ${ }^{12}$ In addition, section 6 of the FTCA granted the FTC broad investigatory powers; ${ }^{13}$ however, despite several unsuccessful attempts to alter the language to expressly

rule was subsequently withdrawn and an alternative rule was proposed on August 17, 1971; the new rule provided that the required octane number was the average of the research and motor octane numbers. On December 16, 1971 the revised rule was issued, effective March 15, 1972, 16 C.F.R. $\$ 422.1$ (1972). This was the final action of the Commission, effective but for a stay of the District Court entered by Judge Aubrey E. Robinson, Jr., 340 F. Supp. at 1350.

5. 16 C.F.R. $\$ \$ 1.11-.16(1972)$.

6. See 15 U.S.C. $\$ \S 41-58(1970)$.

7. Id. $\S 46(\mathrm{~g})$.

8. 340 F. Supp. at 1348-49. See note 15 infra.

9. Widespread demand for greater assistance in the enforcement of the antitrust laws led to the establishment of the Federal Trade Commission. For a history of the formation of the FTC, see Baker \& Baum, Section 5 of the Federal Trade Commission Act: A Continuing Process of Redefinition, 7 VIIL. L. REv. 517 (1962),

10. Sentiment ran from that of desiring a purely investigatory body to that of wanting to grant broad rule-making powers. See Baker \& Baum, supra note 9, at 525-27; 51 CONG. REC. 8845, 9047, 9056 (1914).

11. Act of Sept. 26, 1914, ch. 311, 38 Stat. 717. The scope of the Commission's interest at this time was limited to "unfair methods of competition." Id. at 719. The Commission's area of concern was wideued by the Wheeler-Lea Amendment, Act of March 21, 1938, ch. 49, $\$ 3,52$ Stat. 111. This Act added the words "unfair or deceptive acts or practices" to the language of section 5(a)(6), 15 U.S.C. $\S 45(a)(6)$ (1970), thus making it clear that the Commission can protect the consumer through direct means as well as through the protection of competition.

12. Id. $\S 45$.

13. Id. $\$ 46$. 
grant the Commission legislative rule-making authority, ${ }^{14}$ it was only in the context of those investigatory powers that any reference was made to rules or regulations. ${ }^{15}$ During the past decade, the FTC was expressly granted rule-making power over certain activities of specified industries. ${ }^{16}$ Significantly, the statutory language in these specific grants unore closely resembles the typical language of grants of rule-making authority to other agencies than it does the original language of section $5 .^{17}$

The FTC had traditionally exercised its authority almost entirely through its section 5 power to issue cease and desist orders, although non-bimding trade practice rules were frequently issued and adhered to voluntarily by the industries concerned. ${ }^{18}$ In 1962 ,

14. See 51 Cong. REC. $9047-50,9056-57$ (1914). It was mentioned in debate that the House Committee on Interstate and Foreign Commerce had considered and purposely deleted amendments which would make the Commission's mandate and powers clearly analogous to those of the Interstate Commerce Commission. The feeling was expressed that the broad area of interest of the FTC would not allow the expertise achieved by the ICC in regulating a narrow industry. Concern was also expressed over the effect of such powers on state rules already in force as they related to the proposed legislation.

The debate on the Senate-House Conference Report raised questions concerning the powers of the Commission. At that time, Congressman Covington, one of the sponsors of the bill, stated that the Commission would have no power to prescribe methods of competition to be used in the future. He went on to point out that "[i]n issuing its orders [the Commission] will not be exercising power of a legislative nature." Id. at 14,932.

It was also suggested that the Commission would in no sense exercise a legislative function such as that which is exercised by the ICC. Committee member Stevens remarked that "[w]e desired clearly to exclude that authority from the power of the commission." Id. at 14,938.

15. 15 U.S.C. $\& 46(\mathrm{~g})(1970)$. This section grants the Commission power "[f]roin time to time to classify corporations and to make rules and regulations for the purpose of carrying out the provisions of sections 41 to 46 and 47 to 58 of this title." Id.

16. Wool Products Labeling Act, 15 U.S.C. \$§ 68-68j (1970); Fur Products Labeling Act, id. $\S \S 69-69$ j; Textile Fiber Products Identification Act, id. $\$ \S 70$ 70k; Flammable Fabrics Act, id. §§ 1191-1204; Fair Packaging and Labeling Act, id. $\S \S 1451-61$. The original language of the Flammable Fabrics Act, 67 Stat. 112 (1953), was similar to that of the FTCA. This language was amended to make the Act similar in format to the other above-mentioned statutes, specifying the subjects upon which rules could be issued and expressly stating that a violation of such rules would constitute a violation of the FTCA. 81 Stat. 571 (1967). The purpose of the amendinent was to provide for regulations "to be issued under rulemaking procedures rather than having them fixed by law ...." H.R. ReP. No. 972, 90th Cong., 1st Sess. 1 (1967).

17. See, e.g., Communications Act of 1934, 47 U.S.C. $\$ 195(i)$ (1970) (granting rule-making power to the FCC); Natural Gas Act, 15 U.S.C. $\$ 7170$ (1970) (granting rule-making power to the FP.C).

18. Trade practice rules were promulgated, often at the initiative of the indus- 
however, the Commission amended its rules and procedures to prescribe a method for the adoption of "Trade Regulation Rules," which were to have the force of law. Through this mode of enforcement the FTC could simply charge the violator with an act contrary to the rule; it would then only be required to prove a violation of the rule rather than satisfy the more onerous burden of showing that the act was an unfair trade practice within the meaning of the FTCA. ${ }^{20}$

Pursuant to this new procedure and prior to the promulgation of the Gasoline Octane Rule, the FTC had issued such rules in a variety of areas. The most ambitious of these was a rule relating to the prevention of unfair or deceptive advertising and labeling of cigarettes. ${ }^{21}$ In response to a challenge mounted by the cigarette industry, ${ }^{22}$ the Commission, in promulgating the rule, issued an extensive statement articulating the basis for its authority to promulgate Trade Regulation Rules. ${ }^{23}$ In support of the Commission's claimed authority, the statement cited the "rules and regulations" language of section $6(\mathrm{~g}),{ }^{24}$ arguing that the word "rules" in section $6(\mathrm{~g})$ is properly defimed as in the Administrative Procedure Act: "[T]he whole or part of an agency stateinent of general or particular applicability and future effect designed to implement, interpret, or prescribe law or policy. . .."25 The Commission further relied on its statutory grant of authority to "prevent" the use of "unfair methods of competition" and "unfair or deceptive acts or procedures." 26 Taking the view that the authority to issue cease

tries involved, to prescribe a voluntary course of action for the industry and to provide for an advance opinion from the Commission as to the legality of such action. These rules did not have the force of law. When the Commission took legal action in such a case, the charge was not a violation of the trade practice rule but of the underlying statute. In such proceedings, the FTC was required to prove de novo the unfairuess of the action and was not permitted to rely pon the rule. In the Commission's present procedures and rules of practice, these rules are also referred to as Industry Guides. 16 C.F.R. $\$ \S 1.5,1.6$ (1972). For examples of such trade practice rules, see $i d$. $\$ \$ 22$ (frozen food industry), 139.1 (wine industry), 152 (hosiery industry), 209 (grocery industry).

19. 27 Fed. Reg. 4609 (1962). See 16 C.F.R. $\$ \$ 1.11-.16$ (1972).

20. For a list of other statutes violations of which also constitute violations of the FTCA, see note 16 supra and accoinpanying text.

21. 29 Fed. Reg. 8324 (1964), as revised, id. at 12,626, text deleted and crossreference added, 30 Fed. Reg. 9485 (1965).

22. See 29 Fed. Reg. 8324, 8365 (1964).

23. Id. at 8364 .

24. Id. See 15 U.S.C. $\$ 46(\mathrm{~g})(1970)$.

25. 5 U.S.C. $\$ 551(4)(1970)$.

26. 15 U.S.C. $\$ 45(\mathrm{a})(6)(1970)$. 
and desist orders ${ }^{27}$ is only one vehicle by which the agency was intended to exercise its general powers, the Commission asserted that substantive rule-1naking power was a necessary implication of Congress' establishment of the FTC as not merely a quasi-court but rather as an administrative agency. ${ }^{28}$ The agency argued that the mandate to "prevent" unfair competition and practices is so broad that, absent express statutory language to the contrary, the powers which are necessary and proper to the fulfillment of the directive are to be implied from the mandate. Perhaps recognizing the implicit weakness of its position, however, the Commission devoted a vast portion of its argument to the proposition that such power is also desirable and advantageous to the efficient performance of its duties. ${ }^{29}$ Despite the pains the Commission took to support its authority, Congress expressly pre-empted that position by passmg cigarette-labeling legislation and superseding, without comment, several other rules. ${ }^{30}$

Prior to the National Petroleum Refiners decision, the general concensus among commentators had been that the Commission was significantly weaker in its statutory rule-making authority than its companion agencies; ${ }^{31}$ although rule-making authority was con-

27. Id. $\S 45(\mathrm{~b})$.

28. 29 Fed. Reg. 8369 (1964).

29. Id. at 8366 . For the argument that, even absent a separate conferment of rule-making power, an agency with a degree of discretion possesses implied power (though of questionable legal effect) to the extent that it can state in advance what its attitude will be, see Davis $\$ 6.16$ (Supp. 1970).

30. The Trade Regulation Rule relating to the unsolicited mailing of credit cards, 35 Fed. Reg. 4614 (1970), rescinded, 36 Fed. Reg. 45 (1971), was superseded by provisions in the Truth in Lending Act, 15 U.S.C. $\$ \$ 1642-44$ (1970). The proposed rule relating to shipment of unordered merchandise, 35 Fed. Reg. 10,116 (1970), public hearing cancelled, id. at 14,328, was superseded by provisions of the Postal Reorganization Act, 39 U.S.C. $\$ 3009$ (1970). The rule relating to the prevention of unfair or deceptive advertising in labeling of cigarettes, 29 Fed. Reg. 12,626, 15,570 (1964), was pre-empted by the Federal Cigarette Labeling and Advertising Act, 15 U.S.C. $\$ \$ 1331-40$ (1970). In the case of the cigarette rule, Congress made it clear that it was not commenting on or changing the FTC authority by its action. See Act of July 27, 1965, Pub. L. No. 89-92, § 5, 79 Stat. 283.

31. See generally Baker \& Baum, supra note 9; R. Burris \& H. Teter, Antitrust: Rulemaking v. Adjudication in the FTC, 54 GEo. L.J. 1106 (1965); Handler, Unfair Competition, 21 Iowa L. REv. 175 (1936); Shapiro, The Choice of Rulemaking or Adjudication in the Development of Administrative Policy, 78 Harv. L. Rev. 921 (1965); Weston, Deceptive Advertising and the Federal Trade Commission: Decline of Caveat Emptor, 24 FED. BAR J. 548 (1964). But see DAvis $\$ \S 6.16,6.18$ (Supp. 1970); Forte, The Food and Drug Administration, the Federal Trade Commission and the Deceptive Packaging of Foods, 40 N.Y.U.L. REv. 
ceded to be desirable for the Commission, congressional action was felt to be necessary to grant such authority. Judicial review of the FTC's substantive rule-making authority did not occur prior to 1962, however, because the Commission had not attempted to issue such substantive rules. When the FTC did begin to assert this authority, judicial review was effectively circumvented by the fact that the rules issued were either non-controversial or, if controversial, soon superseded by congressional regulation. ${ }^{32}$ Therefore, although the courts had explored the FTC's other powers, ${ }^{33}$ as the advantages of a rule-making power became clear to the agency and the FTC accordingly began attempting to assert such a power, little judicial basis existed to determine the validity of the outcome. ${ }^{34}$

Relying heavily upon the legislative history of the FTCA, the National Petroleum Refiners court held that the Commission lacks the requisite statutory authority to issue Trade Regulation Rules. ${ }^{35}$ The court noted that at the time of Congress' 1914 debate of the FTCA there were several unsuccessful attempts to amend the bill and to create a more powerful agency, ${ }^{36}$ and the court concluded that Congress intended specifically to withhold the rule-making power-which would have been clearly granted if the proposed amendinents to the bill had been approved-from the

860 (1965); Wegman, Cigarettes and Health: A Legal Analysis, 51 CORnELL L.Q. 678 (1966).

32. See note 30 supra for citations concerning the supersession of the cigarette rule and other Trade Regulation Rules. Heretofore the courts had refused to enjoin the FTC from having proposed hearings preliminary to the issuance of Trade Regulation Rules, holding that the cases would be ripe for adjudication only if a rule was issued. Bristol-Meyers v. FTC, 424 F.2d 935 (D.C. Cir.), cert. denied, 400 U.S. 824 (1970) (proposed rule regulating certain aspects of commerce in medicines); Lever Brothers Co. v. FTC, 325 F. Supp. 371 (D. Me. 1971) (proposed rule prohibiting sale of synthetic detergents without disclosing ingredients and warning of the contribution to pollution of any phosphates).

33. See note 42 infra.

34. With respect to the National Labor Relations Act, however, the Supreme Court had said that "[t]he 'national meaning of words cannot be displaced by reference to difficulties in administration.'" Addison v. Holly Hill Fruit Prods., Inc., 322 U.S. 607, 617 (1944), quoting Commonwealth v. Grunseit, 67 Comm. L.R. 58, 80 (Austl. 1943).

35. 340 F. Supp. at 1345-47. In support of its interpretation, the court cited the views of the author of the bill, Congressman Covington, and other statements made in the course of the House debate concerning what effect the wording of the bill would have. 51 CoNG. REc. 8845, 9056-57, 14,932, 14938 (1914). See note 14 supra.

36. 340 F. Supp. at 1346 , citing 51 CoNG. Rec. 9047-50, 9056-57 (1914). 
Commission. In addition, the court rejected the Commission's contention that "rule," in section $6(\mathrm{~g})$ of the FTCA, ${ }^{37}$ should be defined as it is in the Adinistrative Procedure Act. ${ }^{38}$ The court noted that the passage of the FTCA preceded that of the APA by over thirty years and that there was no cross-reference between the two statutes; ${ }^{39}$ froin these facts the court drew the inference that Congress did not expect the FTC to engage in substantive ruleinaking activity in the manner prescribed in the APA. The court further refused to interpret the statutory provision authorizing the Commission to "prevent" unfair methods of competition ${ }^{40}$ to constitute an implied rule-making power; ${ }^{41}$ although it acknowledged that such imprecise grants of power to other agencies have been sustained in the past, ${ }^{42}$ the court indicated that such cases did not in-

37. 15 U.S.C. $\$ 46(\mathrm{~g})(1970)$.

38. 5 U.S.C. $\& 551(4)$ (1970).

39. The court noted that the NLRA was passed prior to the APA and was amended specifically to refer to the APA, see 29 U.S.C. $\$ 156$ (1970); however, Congress found no such change necessary in the FTCA. $340 \mathrm{~F}$. Supp. at 1348.

40. 15 U.S.C. $\& 45(a)(6)(1970)$.

41. $340 \mathrm{~F}$. Supp. at 1349 . The court specifically pointed to the next paragraph in section 5(b), 15 U.S.C. $\$ 45(b)$ (1970), and its requirement that adjudicative proceedings be used with the issuance of cease and desist orders.

42. 340 F. Supp. at 1349. In several cases, the Supreme Court had sustained imprecise grants of power; however, these cases are distinguishable since there was not a strong legislative history to the contrary as in the case of the FTCA. See United States v. Oregon, 366 U.S. 643 (1961) (holding that the legislative history of statute was not strong enough to overcome the plain language of the statute); United States v. Public Utilities Commissions, 345 U.S. 295 (1953) (holding the legislative history not strong enough to negate a grant of power to the commission); National Broadcasting Co., Inc. v. United States, 319 U.S. 190 (1943) (holding the legislative history not to clearly negate implied grant of legislative power to FCC). But see Schechter Poultry Corp. v. United States, 295 U.S. 495 (1935) (where the Court analyzed Congress' generally limited ability to delegate legislative power in the form of creating quasi-judicial commissions). Although the District of Columbia Circuit had leld that agencies cannot regulate in such a manner as to expand the statutory power, FTC v. B.F. Goodrich Co., 242 F.2d 31 (D.C. Cir. 1951) (findings of fact being expressed in "dollars" while the rule was expressed in "pounds," the rule was therefore invalid since it was not properly based upon findings as required by the statute); Textile \& Apparel Group, Am. Importers Ass'n v. FTC, 410 F.2d 1052 (D.C. Cir.), cert. denied, 396 U.S. 910 (1969) (holding Wool Act's authorizing FTC to require labeling and authorizing the issuance of cease and desist orders did not authorize rule under which imports were intercepted and tested), in Umited States v. Morton Salt Co., 338 U.S. 632 (1950), the Supreme Court, by reading the FTCA as an integrated whole, affirmed the power of the FTC to apply its regulation beyond the literal language of the individual sections of the statute.

The National Petroleum Refiners decision exaggerates the apparent distinctions in the language of the various statutes granting rule-making authority to administra- 
volve the overwhelmingly contrary legislative history of the FTCA. ${ }^{43}$ The court found further support for its interpretation of the FTCA in the particularity of the subsequent grants by Congress of substantive rule-making power to the agency, ${ }^{44}$ the fact that Congress later granted such rule-making power to the FTC in particular areas $^{45}$ was seen by the court as an implication that Congress had not intended to grant general rule-naking power in the FTCA. The court also interpreted the congressional action of superseding several Trade Regulation Rules as an implicit rejection of the efficacy of such rules, and the court attributed some signifi-

tive agencies. See notes 16,17 supra and accompanying text. While differences in the statutes do exist, it is nonetheless true that the language in each of the statutes discussed by the court is imprecise. Indeed, given the parallel structure and functions of Inany administrative agencies and the geueral similarity in statutory language granting rule-making authority to these bodies, the court's emphasis on slight distinctions that exist in such language seems less than convincing. Similarly, in interpreting Congress' motives in superseding several of the FTC's Trade Regulation Rules, the court ignored the fact that Congress clearly concluded that the action was not to be taken in any way as affecting or commenting on the Commission's rule-making authority.

The NLRB amendment, referred to at $340 \mathrm{~F}$. Supp. 1348, was likewise misunderstood. There would seem to be no need to counment on the meaning of "rules" with respect to APA defimitions unless the meaning was to be other than that given generally for other agencies. Thus, the FTC's argument would seem to be following the court's suggestion in looking at the FTCA as an integrated whole as directed by United States v. Morton Salt Co., 338 U.S. 632 (1950). Reading the statute as a whole, the mandate to "prevent" could be interpreted as granting to the FTC the authority ordinarily given to agencies, with any further language in the FTCA being interpreted as simply adding to that power. Perhaps such ambiguity in this and other statutes suggests a general need for the clarification of the powers of administrative bodies.

43. 340 F. Supp. at 1349, citing United States v. Oregon, 366 U.S. 643 (1961); United States v. Public Util. Comm'ns, 345 U.S. 295 (1953); National Broadcasting Co. v. United States, 319 U.S. 190 (1943).

44. $340 \mathrm{~F}$. Supp. at 1347 n.17. The court further noted the amendment to the Flammable Fabrics Act, 81 Stat. 570 (1967), and the statement of the report of the House Committee on Interstate and Foreign Cominerce that the amendment was desigued to make the act more flexible by permitting "regulations to be issued under substantive rule-making procedure rather than having them fixed by law as is now the case." H.R. REP. No. 972, 90th Cong., 1st Sess. 1 (1967).

The court suggested that there was a similar need to spell out the substantive rule-making authority in the case of section $6(\mathrm{~g})$ of the FTCA. The court stated that the Commission's traditional failure to assert such rule-1naking authority indicated the FT.C's awareness that it had not been granted this rule-making authority originally, $340 \mathrm{~F}$. Supp. at 1347 . The court further noted the repeated admission of the FTC that it has no power to promulgate substantive rules of law, citing FTC Annual Reports, id. at 1347, n.16, and testimony before Senate and House Committees, id. at 1350 n.33.

45. See note 16 supra. 
cance to the fact that Congress has not yet passed a pending bill ${ }^{10}$ which would amend section $6(\mathrm{~g})$ of the FTCA so as to authorize the Commission to legislate rules defining the unfair or deceptive practices referred to in section $5(\mathrm{a})(1) .{ }^{17}$ The court summarized the FTC's argunent as a "bootstrap operation," requiring not a construction but an imperinissible enlargement of the statute. ${ }^{48}$

The decision in National Petroleum Refiners confirms the common prior impression that the FTC was operating beyond its statutory authorization in proinulgating Trade Regulation Rules. ${ }^{40}$ The district court's documentation of the legislative history makes it clear the FTC was indeed meant to be distinct from the other bodies in its limited power-the congressional intent was to withhold rulemaking authority from the Commission. ${ }^{50}$ Nevertheless, the decision will have significant effects. At the most obvious level, the case $^{51}$ will lead to the nullification of the small conglomeration of Trade Regulation Rules which the Commission has promulgated in recent years. ${ }^{52}$ The ultimate effect on consumers is not imme-

46. See note 53 infra.

47. It is dangerous to speculate as to why Congress failed to pass legislation. The court merely mentioned this in passing by way of a footnote. $340 \mathrm{~F}$. Supp. at 1350 n.33.

48. $I d$. at 1350 .

49. See note 31 supra and accompanying text.

50. See note 35 supra and accompanying text. A thorough reading of the cited debate uncovers a congressional hesitancy to grant sweeping power over a broad area. This is similar to the concern expressed recently with respect to bills now pending in Congress which would grant the FTC rule-making authority in unquestionable terms. See 117 CoNG. REc. S17,828 (remarks of Senator Moss), S17,857 (remarks of Senator Hruska), S17,873 (remarks of Senator Cotton), S17,884 (remarks of Senator Cooper) (daily ed. Nov. 8, 1971).

51. The FTC filed its appellate briefs on July 19, 1972; the appellees filed their reply brief on August 16, 1972.

52. 16 C.F.R. $\$ \$ 401-06,409-10,412-14,417-18,419,422-24$. The absence of earlier court challenges to these regulations would seem to indicate their non-controversial nature.

Most of the more important regulations have been superseded by Congress. See note 30, supra. Pending the final outcome of its rule-making authority, the FTC has continued to follow its procedure for the promulgation of Trade Regulation Rules. On January 4, 1973 the FTC released a revised Trade Regulation Rulo dealing with the presentation of consumer claims and defenses in credit sales. 38 Fed. Reg. 892 (1972). The order of the National Petroleum Refiners court declared null and void only the rule relating to the posting of gasoline octane numbers. While any enforcement of other Trade Regulation Rules would inevitably result in their being struck down, the FTC was not enjoined from the promulgation of new rules.

Realizing the uncertain status of its Trade Regulation Rules, the FTC, in issuing its rule on door to door sales, insisted that it has the authority to promulgate 
diately apparent, however, since the impact of the case in this respect is largely dependent upon the changes in the FTC authority which National Petroleum Refiners could generate in Congress and upon the ensuing changes in FTC activity. The decision inay well urge Congress to accelerate its action on bills now pending which would give the Commission rule-making authority. ${ }^{53}$ Thus, the importance of National Petroleum Refiners is found in the fact that the case may serve as a catalyst in forcing a long-needed crystalization of the imprecisely-worded powers of the FTC. Congress may now be forced to consider the advantages and disadvantages of allowing an agency governing the broad area encompassed by the FTCA to issue legislative rules with the effect of substantive law.

It is immediately apparent that the ability of the FTC to issue rules would have definite advantages. ${ }^{54}$ Simce the issuance of substantive principles is an implicit part of the Commission's adjudicatory powers, the primary question raised in National Petroleum Refiners was not whether rules are to be made, but ratler the manner in which they will be issued. If such regulations are issued through the process of legislative rule-making, the gathering and evaluation of information is simplified; furthermore, the views of interested persons excluded in a case-by-case adjudicatory process would be considered. ${ }^{55}$ The rule-naking process is not limited by the confines of a quasi-judicial procedure incorporating time-consuming, albeit necessary, safeguards of individual rights; it is more difficult to issue broad, meaningful rules in cases of adjudication

such rules. 37 Fed. Reg. 22934, 22944 (1972), but nevertheless deferred an announcement of an effective date, citing the pending litigation of the Commission's rule-making authority. Id. at 22961.

53. S.986, 92d Cong., 1st Sess. (1971); H.R. 4809, 92d Cong., 1st Sess. (1971). Opposition has been expressed to granting the Commission unrestricted rule-making authority, however, as evidenced by the sixty day congressional veto incorporated into the Senate bill. See 117 CoNG REC. S17,828 (remarks of Senator Moss), S17,857 (remarks of Senator Hruska), S17,873 (remarks of Senator Cotton), S17,884 (remarks of Senator Cooper) (daily ed. Nov. 8, 1971). The House bill, with its less cumbersome procedure, is preferred by the Commission. BNA ANTITRUST AND TraDe REg. REP. No. 560, p. A-1 (1972).

54. See generally Davis, $\$ 6.15$ (Supp. 1970); Shapiro, The Choice of Rulemaking or Adjudication in the Development of Administrative Policy, 78 HARV. L. Rev. 921 (1965). See also 29 Fed. Reg. 8364 (1964).

55. Of course, in adjudication, interested persons may file briefs as amici curiae. For a discussion of the limited allowance made for public participation in informal FTC proceedings and the unclear but limited provisions for intervention of interested parties in formal FTC adjudicatory proceedings, see Comment, Public Participation in Federal Administrative Proceedings, 120 U. PA. L. Rev. 702, 789812 (1972). 
where the Commission is seeking justice in the individual case being prosecuted. It is also true that adjudicative rules have retroactive effect, thus working unforeseen hardships on the first groups prosecuted and resulting in an unfair stigmatization of those individuals as lawbreakers. Given the Commission's necessarily limited resources, continued restriction to the use of less efficient cease and desist orders may, in effect, prevent it from providing adequate protection to the consumer. By issuing rules, an agency may be better equipped to utilize the expertise of its staff to inake imdustrywide rulings which would provide advance guidance as to the lawful limits of industry action..$^{56}$

There are, however, certain dangers involved in granting rulemaking authority over such a broad area as the FTC regulates. Unchecked, this authority could result in an enormously powerful agency. Also, in a grant of discretionary power over a broad area to a single body, such an agency may be hard-pressed to bring to bear the same degree of expertise which agencies confined to more narrow areas could develop. ${ }^{57}$ These considerations have prompted, in the pending congressional grant of authority, an evident desire for reservations and safeguards. ${ }^{58} \mathrm{~A}$ balancing of conflicting considerations could properly lead to the enactment of a statute quite similar to that proposed by S. 986,59 which would grant the FTC rule-making authority, while retaining a congressional veto over the Commission's rules. The National Petroleum Refiners decision thus may prompt long-needed legislative clarification and reform with respect to the Commission's powers.

56. But cf. text accompanying note 57 infra.

57. Weston, Deceptive Advertising, supra note 31, at 571.

58. 117 Cono. ReC., supra note 50. See note 53 supra.

59. S. 986, supra note 53. 